\title{
GENDER DIFFERENCES RELATED TO LIFESTYLE BEHAVIOUR OF UNIVERSITY STUDENTS
}

\author{
Daiva Vizbaraitė ${ }^{1}$, Julija Kleivaitė ${ }^{1}$, Vaidas Mickevičius ${ }^{2}$ \\ Lithuanian Sports University ${ }^{1}$, Kaunas, Lithuania \\ University of Applied Engineering Sciences, ${ }^{2}$ Kaunas, Lithuania
}

\begin{abstract}
Background. A healthy lifestyle is the one of the most relevant subjects in a modern society comprising three factors - healthy diet, sufficient physical activity, and absence of harmful habits (Strukčinskiene et al., 2014). It has been pointed out that healthy lifestyle behavioural patterns contribute to the prevention of diabetes mellitus type II, cardiovascular, and oncological diseases (Javtokas et al., 2014).

Studies performed in different countries have discovered that students' dietary habits do not correspond to the recommendations of the World Health Organization on healthy diet (Akhtar Zareen, \& Sarmad, 2018; Česnavičiené, Proškuvienė, \& Motiejūnaite, 2015). In their study, Sigmundova, Chmelik, Sigmund, Feltlova, and Frömel (2013) found that the lowest level of physical activity was reached by only two thirds of students. The prevalence of harmful habits was also very high: more than half of students used tobacco during the last 12 months, and about $92 \%$ of students used alcohol over the last year (Dobrovolskij \& Stukas, 2014).

Literature review revealed that recently a number of studies analysing students' lifestyle patterns were performed, however, there is still a lack of studies on lifestyle behaviour among the Lithuanian Sports University students.

Methods. Questionnaires and statistical analysis.

Results. The results showed that meat consumption was indicated by twice more males than females $(p<.05)$. More males consumed ice cream, while yoghurt was preferred more frequently by females $(p<.05)$. Fried potatoes were used more frequently by males $(p<.05)$. With the respect to sedentary lifestyle, high intensity activity and moderate intensity activity, there were no differences between males and females, however, more females than males walked $(p<.05)$. Beer consumption was more prevalent between males while wine consumption was more common between females $(p<.05)$.
\end{abstract}

Keywords: dietary habits, physical activity, harmful habits, students, gender differences.

\section{INTRODUCTION}

$\mathrm{H}$ ealthy lifestyle is one of the most relevant issues in a modern society comprising three factors - healthy nutrition, sufficient physical activity, and the absence of harmful habits (Strukčinskiene et al., 2014). Literature shows that healthy lifestyle behavioural patterns contribute to the prevention of many diseases, such as diabetes mellitus type II, cardiovascular, and oncological diseases (Javtokas et al., 2014).

Diet is closely associated with health and the development of diseases. The consumption of sugar-sweetened foods high in lipids or sodium may increase the risk of diabetes mellitus and cardiovascular diseases. Health issues are also closely linked to the insufficiency of nutrients that can be found in certain foods (Petkevičienè, Kriaučionienė, \& Petrauskienė, 2014). Literature presents many factors that are related to dietary habits of students. Some factors are associated with taste properties and appearance, others are related to the surroundings of students (Deliens, Clarys, De Bourdeaudhuij, \& Deforche, 2014).

Physical activity is the next constituent of healthy lifestyle. According to the World Health 
Organization, active lifestyle has many benefits: it improves the function of the cardiovascular system, increases muscle capacity, strengthens bones, and even contributes to prevention of depression (WHO, 2010). Studies have defined the factors that contribute to low level of physical activity of students (Juškelienė \& Česnavičienè, 2017). Literature also presents the groups of factors that influence physical activity. One group comprises individual choice; the other is based on the example of the role models (Deliens et al., 2015). The association between the differences of physical activity and the study programme or even the day of the week was indicated (Dobrovolskij \& Stukas, 2015; Sigmundova et al., 2013).

The prevalence of harmful habits among students is significantly high. During the last 12 months, daily tobacco smoking was reported by more than half of students, and consumption alcohol beverages was pointed out by $92 \%$ of students (Dobrovolskij et al., 2014). Interestingly, males consumed alcohol more frequently than females, but females began drinking earlier than males (Davoren, Shiely, Byrne, \& Perry, 2015; MorenoGomez et al., 2012). It is stated that the frequency of alcohol consumption also is associated with the choice of accommodation during studies. Authors indicate that males living in hostels consumed alcohol more frequently, while females that rented a flat/house used alcohol more frequently (Davoren et al., 2015). The distribution of smoking in both genders was similar; respondents indicated that they began to smoke at the age of $16.4 \pm 2.3$ (MorenoGomez et al., 2012). A comparison of smoking patterns between different Lithuanian universities showed that daily smoking was reported by twice more students of Vilnius University than students of the Lithuanian University of Health Sciences (Samsonienè \& Zimnicka, 2013).

Literature review revealed that recently a number of studies analysing students' lifestyle patterns were performed, however, there is still a lack of studies on lifestyle behaviour among the Lithuanian Sports University students.

\section{METHODS}

Questionnaire survey. Students were asked to answer questions presented in a questionnaire, such as diet, dietary patterns, the consumption of snacks, and the frequency of the use of foods listed, and mark their age, height, weight, and gender.
The questionnaire also comprised questions about harmful habits: smoking and alcohol use. One part of the interview was comprised using the International Physical Activity Questionnaire (IPAQ).

Statistical analysis. The data obtained were processed by methods of statistics. Relationships between qualitative determinants were evaluated by chi-square $\left(\chi^{2}\right)$ criterion. Student's $(t)$ criterion was used to calculate and verify means. Following the Ipaq Research Committee (2016) directions, physical activity was calculated also in MET units. The significance level was set at $p<.05$. The collected data were analysed using the SPSS software version 22 .

\section{RESULTS}

The results of the study showed that approximately half of the female respondents (45.3\%) and more than two thirds of males (35.1\%) chose foods according to their taste properties. Both genders were the least influenced by family members ( $6.3 \%$ of females and $8.8 \%$ of males). The majority of females $(78.1 \%)$ and males $(70.7 \%)$ had $4-5$ meals per day. Only the minority of respondents ( $4.7 \%$ of females and $1.7 \%$ of males) consumed only 2 meals per day. The data revealed that more than half of participants did not have regular dietary patterns $(62.5 \%$ of females and $58.6 \%$ of males). The analysis of the data showed that daily breakfast consumption was pointed out by respondents mostly ( $89.1 \%$ of females and $77.6 \%$ of males). The distribution of occasional breakfast consumption or breakfast skipping was very similar in students. The consumption of snacks was indicated by both genders ( $68.4 \%$ of females and $65 \%$ of males), while only $5.3 \%$ of females and $10 \%$ of males reported not having snacks at all during the day.

The frequency of consumption of different foods is presented in Table 1. Meat consumption on daily basis was reported by $50 \%$ of males and $29.7 \%$ of females (differences are statistically significant, $p<.05$ ), $1.6 \%$ of females and $3.4 \%$ of males never consumed meat or used it less often than once per month. Meat consumption twice per week among females and males showed statistically significant difference (17.2\% of females and $1.7 \%$ of males). The use of fish and meat products according to gender did not differ statistically significantly. Approximately one third of both genders consumed fish once per week, and $7.8 \%$ of females and 10.3 of males indicated that they never used fish. 
Daiva Vizbaraitè, Julija Kleivaitè, Vaidas Mickevičius

GENDER DIFFERENCES RELATED TO LIFESTYLE BEHAVIOUR OF UNIVERSITY STUDENTS

Table 1. Frequency of meat, meat products, and fish consumption according to gender

\begin{tabular}{|c|c|c|c|c|c|c|}
\hline \multirow{2}{*}{ Frequency } & \multicolumn{2}{|c|}{ Meat } & \multicolumn{2}{|c|}{ Fish } & \multicolumn{2}{|c|}{ Meat products } \\
\hline & Females & Males & Females & Males & Females & Males \\
\hline $\begin{array}{l}\text { Never or less often than } \\
\text { once per month }\end{array}$ & 1.6 & 3.4 & 7.8 & 10.3 & 15.6 & 14 \\
\hline Once per month & 0 & 0 & 0 & 0 & 18.8 & 12.3 \\
\hline 2-3 times per month & 4.7 & 0 & 25 & 19 & 15.6 & 7 \\
\hline Once per week & 4.7 & 5.2 & 28.1 & 25.9 & 21.9 & 14 \\
\hline Twice per week & 17.2 & 1.7 & 34.4 & 31 & 9.4 & 21.1 \\
\hline 3-4 times per week & 18.8 & 19 & 4.7 & 10.3 & 7.8 & 17.5 \\
\hline 5-6 times per week & 23.4 & 20.7 & 0 & 3.4 & 6.3 & 8.8 \\
\hline \multirow[t]{2}{*}{ Daily } & 29.7 & 50 & 0 & 0 & 4.7 & 5.3 \\
\hline & \multicolumn{2}{|c|}{$\begin{array}{c}\chi^{2}=13.86, l l s=6, \\
p=.03\end{array}$} & \multicolumn{2}{|c|}{$\begin{array}{c}\chi^{2}=4.4, l l s=5 \\
p=.49\end{array}$} & \multicolumn{2}{|c|}{$\begin{array}{c}\chi^{2}=9.15, l l s=7 \\
p=.24\end{array}$} \\
\hline
\end{tabular}

Consumption of meat products once per week was pointed out by $21.9 \%$ of females, while $21.1 \%$ of males reported having meat twice per week.

Frequency of milk, ice cream and yoghurt consumption according to gender is presented in Table 2 . The results showed that milk consumption was pointed out by the majority of females; they used milk 5-6 times per week or daily while males reported having milk daily. There was statistically significant difference of ice cream and yoghurt consumption between genders: more males than females had ice cream 2-3 times per month while yoghurt was consumed more frequently by females.

More than half of females and more than one third of males reported consuming sour cream and cream never or less often than once per month. Curd and curd cheese consumption differed between genders: the highest percentage of females consumed these products once or twice per week while the number of the distribution of males was equal in three groups: one group of males reported never or rarely consuming curd and curd cheese, the other - once per week, and the third group of males consumed curd and curd cheese daily.

Females (36.8\%) reported consuming fermented cheese 3-4 times per day while $20 \%$ of males used fermented cheese 2-3 times per month, the same percentage of males - twice per week, and the use of fermented cheese twice per day was also reported by the same number of males. The highest percentage of both genders reported never using butter and margarine or consumed it less often than once per month. Males (27.6 \%) used eggs twice per week while $20 \%$ of females consumed eggs once per week, and another 20\%-3-4 times per week. Approximately, half of females $(42.2 \%)$ did not

Table 2. Frequency of milk, ice cream and yoghurt consumption according to gender (\%)

\begin{tabular}{|c|c|c|c|c|c|c|}
\hline \multirow{2}{*}{ Frequency } & \multicolumn{2}{|c|}{ Milk } & \multicolumn{2}{|c|}{ Ice ream } & \multicolumn{2}{|c|}{ Yoghurt } \\
\hline & Females & Males & Females & Males & Females & Males \\
\hline Never or less often than once per month & 7.8 & 13.8 & 7.8 & 25 & 6.3 & 10.5 \\
\hline Once per month & 1.6 & 3.4 & 18.8 & 17.9 & 1.6 & 8.8 \\
\hline 2-3 times per month & 9.4 & 10.3 & 28.1 & 32.1 & 6.3 & 15.8 \\
\hline Once per week & 7.8 & 12.1 & 25 & 7.1 & 14.1 & 10.5 \\
\hline Twice per week & 10.9 & 15.5 & 7.8 & 10.7 & 21.9 & 28.1 \\
\hline 3-4 times per week & 18.8 & 15.5 & 7.8 & 3.6 & 28.1 & 21.1 \\
\hline 5-6 times per week & 21.9 & 8.6 & 1.6 & 3.6 & 10.9 & 3.5 \\
\hline \multirow[t]{2}{*}{ Daily } & 21.9 & 20.7 & 3.1 & 0 & 10.9 & 1.8 \\
\hline & \multicolumn{2}{|c|}{$\begin{array}{c}\chi^{2}=6.17, l l s=7 \\
p=.52\end{array}$} & \multicolumn{2}{|c|}{$\begin{array}{c}\chi^{2}=14.88, l l s=7 \\
p=.037\end{array}$} & \multicolumn{2}{|c|}{$\begin{array}{c}\chi^{2}=13.84, l l s=7 \\
p=.05\end{array}$} \\
\hline
\end{tabular}


consume or consumed beans and lentils less often than once per month, and $29.8 \%$ of males used them once per month. The highest percentage of participants of both genders consumed vegetables $3-4$ times per week, only $15.6 \%$ of females and $6.9 \%$ of males used vegetables daily. Fruit consumption was reported by only $6.3 \%$ of females and $3.4 \%$ of males.

Females $(35.9 \%)$ and males (29.85) consumed rice and pasta 3-4 times per week. The use of oat and buckwheat differed according to gender: $23.4 \%$ of females used them daily while $20.7 \%$ of males never used or consumed these products less often than once per month. Females $(26.6 \%)$ consumed boiled potatoes once per month, and males $(25.9 \%)$ - once per week.

Frequency of fried potato consumption showed statistically significant difference. Mostly, females (32.8\%) consumed fried potatoes once per month while males $(25.9 \%)$ - once per week. Potato chips were not consumed or consumed less frequently than once per month by $32.3 \%$ of females and $24.6 \%$ of males. Approximately, one fourth of both genders consumed confectioneries, sweets and chocolate once per week. Daily use of lemonade was reported by only $3.2 \%$ of females and $6.9 \%$ of males; the highest percentage of participants pointed out that they never used lemonade or used it less often than once per month. Frequency of juice consumption differed among genders: $20.3 \%$ of females had juice 2-3 times per week while $15.5 \%$ of males - once per week, $15.5 \%$ - twice per week, and the rest of male participants $-5-6$ times per week.

Students were also asked to point out how many minutes per week had high and moderate intensity activities, how many minutes they spent on walking, and sitting (Table 3). Mean time spent per week on sitting, having high and moderate intensity activities did not show statistical significant difference between genders. However, females 1.5 times more minutes per week spent on walking compared to males (results statistically differed, $p<.05$ ).

Students were also asked to point out smoking habits. The majority of participants $(73.4 \%$ of females and $75.9 \%$ of males) were non-smokers. A comparison of the distribution of daily smokers and social smokers showed that the number of daily female smokers were slightly lower than that of males while considering social smoking this number increased twice (differences were not statistically significant, $p>.05$ ).

Approximately $40 \%$ of both genders reported consuming strong alcohol beverages (>22\%) several times per year, more females (by 10\%), consumed 2-3 times per month and twice more males than females stated that they did not use alcohol. The least number of students (only 3.1\% of females and $5.2 \%$ of males) reported consuming strong alcohol beverages 2-3 times per week.

Frequency of consumption of soft alcohol beverages such as beer and wine was also investigated. According to our results, beer was not consumed by females; $34.4 \%$ of females had beer 2-3 times per month. Daily consumption of beer was reported by $1.7 \%$ of males, $25.9 \%$ of males pointed out that they used beer $2-3$ times per week. Gender differences also were statistically significant. Beer consumption was reported by four times more males (2-3 times per week), and twice more females used beer $2-3$ times per month $(p<.05)$.

Wine consumption was reported by both genders $(43 \%)$, participants pointed out that they consumed wine several times per year, nobody reported having wine daily. The results showed that wine consumption statistically significant differed according to gender. Figure 2 illustrates the higher number of females consuming wine 2-3 times per week, once per week and 2-3 times per month, however, four times more males than females reported not consuming wine at all $(p<.05)$.

\begin{tabular}{|c|c|c|}
\hline \multirow{2}{*}{ Activities } & Females & Males \\
\hline & \multicolumn{2}{|c|}{ Mean \pm SD } \\
\hline Sitting (min/wk) & $1667.19 \pm 843.71$ & $1530 \pm 805.42$ \\
\hline $\begin{array}{l}\text { High intensity activity } \\
(\mathrm{min} / \mathrm{wk})\end{array}$ & $306.72 \pm 373.90$ & $352.74 \pm 321.63$ \\
\hline $\begin{array}{l}\text { Moderate intensity activity } \\
(\mathrm{min} / \mathrm{wk})\end{array}$ & $305.16 \pm 325.74$ & $301.21 \pm 411.44$ \\
\hline Walking (min/wk) & $778.28 \pm 668.53 *$ & $470.01 \pm 519.75^{*}$ \\
\hline
\end{tabular}

Table 3. Comparison of means of time (minutes per week) spent on sitting, high and moderate intensity activities, and walking according to gender

Note. ${ }^{*} p<.05$ 
Figure 1. Frequency of beer consumption according to gender

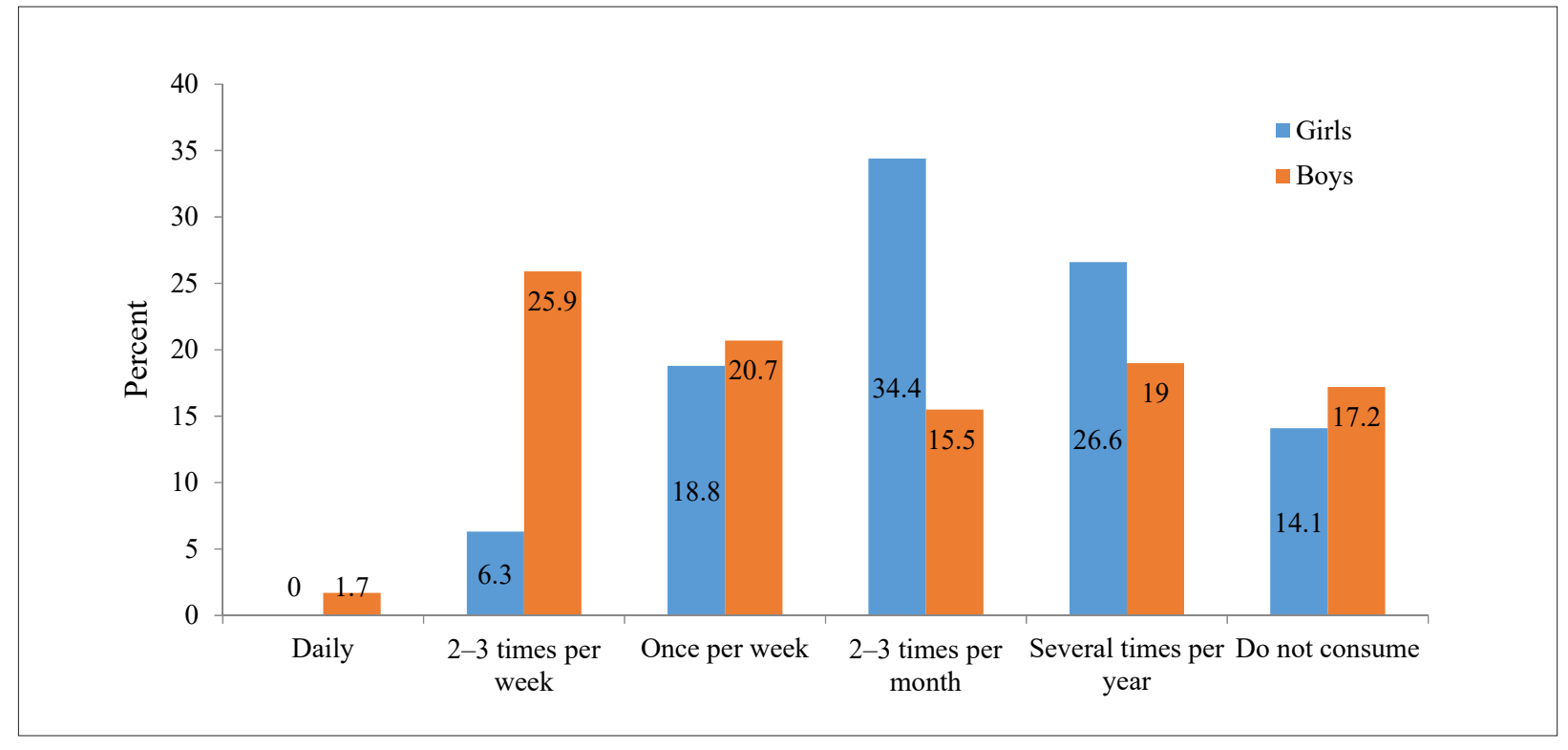

Note. $\chi^{2}=13.89 ; l l s=5 ; p=.02$.

Figure 2. Frequency of wine consumption according to gender

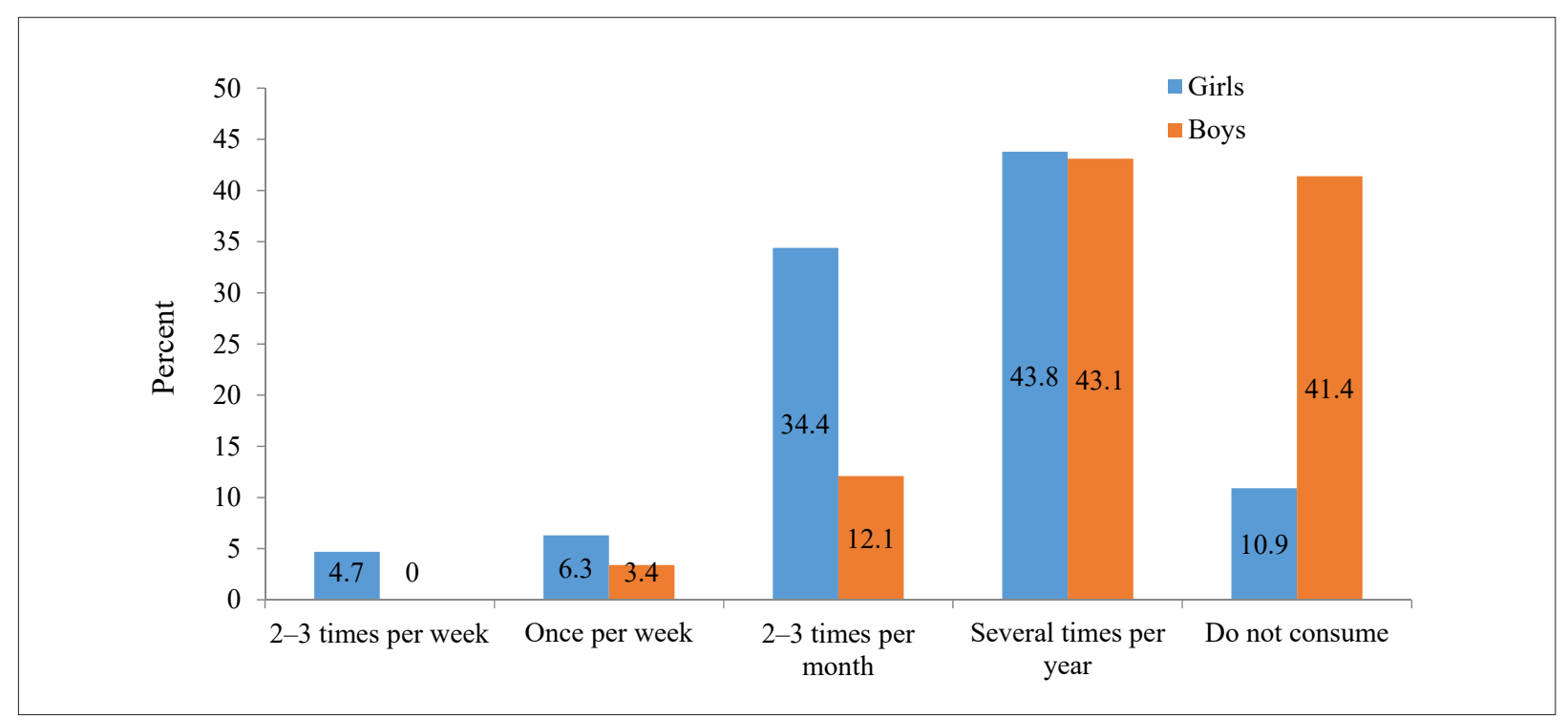

Note. $\chi^{2}=20.67, l l s=4, p=.00$.

\section{DISCUSSION}

The analysis of students' diet shows several basic factors of food choice. Some authors indicate the presence of taste properties (Deliens et al., 2014). Other authors observed that the main criterion of food choice between females was health benefits (Halimic, Gage, Raats, \& Williams, 2018). Our study showed that the majority of students (approximately half of females and one third of males) also indicated taste properties as the main criterion.

Vegetable and fruit consumption is especially important. The Ministry of Health of the Republic of Lithuania (2018) recommends the daily use of fruit and vegetables. Studies show that people who consume seven portions of fruit and vegetables daily have a lower risk for non-infectious diseases 
(Oyebode, Gordon-Dseagu, Walker, \& Mindell, 2014). Our study shows that the use of these foods remarkably differs from the recommendations. We determined that approximately $16 \%$ of females and $8 \%$ of males used vegetables daily; the highest number of students (about $30 \%$ of both genders) reported consuming vegetables only 3-4 times per week. Daily use of fruit was reported by $6.3 \%$ of females and less than half of males, while intake of fruit once per week was pointed out by the majority of students.

Authors of studies have presented different results about daily breakfast consumption. Some of them state that approximately $85.5 \%$ of students have daily breakfast, while according to the others approximately -70\% (Akhtar et al., 2018; Karmakar, Jahan, Banik, Das, \& Rahman, 2016; Musaiger, AlKhalifa, \& Al-Mannai, 2016). The results of our study show similar results. We determined that $89.1 \%$ of females and $77.6 \%$ of males had breakfast daily, and statistically significant difference between genders was not found.

Foreign authors have pointed out that approximately $70 \%$ of students reported having three meals per day (Akhtar et al., 2018), while Lithuanian authors claim that about half of students had 3-4 meals per day (Samsonienè \& Zimnicka, 2013). Our results show that our data slightly differed from the other studies. We have found that the majority of the respondents $(78.1 \%$ of females and $70.7 \%$ of males) consumed $4-5$ meals per day, and $17.2 \%$ of females and one third of males reported having three meals per day.

A comparison of the data obtained in our study and in the studies of other researchers about snack consumption produced similar results. Both studies show that more than $60 \%$ of students consume snacks (Samsonienè \& Zimnicka, 2013).

The Ministry of Health of the Republic of Lithuania (2018) recommends including fish into diet. The other authors also suggests including fish (salmon, herring, tuna etc.,) into diet as disease prevention (Clayton, 2019). However, studies show that more than half of students do not consume fish even once per week (Česnavičienè et al., 2015). Our study shows slightly different results: approximately one third of both genders had fish twice per week, and $7.8 \%$ of females and $10.3 \%$ of males reported never eating fish or just had it once per month, consumption of fish 5-6 times per week was indicated by $3.4 \%$ of males.
Dairy products were consumed daily by $2.5-10 \%$ of students (Česnavičienè et al., 2015). According to our study, approximately one fifth of both genders indicated that they used milk daily, yoghurt was consumed 3-4 times per week by $28.1 \%$ of females, and the same number of males reported having yoghurt twice per week. The other products such as sour cream and cream were used never or consumed very rarely by half of participants, while curd was consumed by four times more males compared to females.

Diet is based on the consumption of products of vegetable origin, some of them are cereals. Studies show that porridge and flakes were consumed daily by only $4 \%$ of students, about $20 \%$ of students used them 3-5 times per week (Česnavičienè et al., 2015). Our results showed that oat and buckwheat were consumed daily by a larger part of respondents compared to the data of other authors $(12.5 \%$ of females and $15.5 \%$ of males). Rice and pasta consumption in other studies was lower compared to our results (Česnavičienė et al., 2015). Authors state that only $3 \%$ of students consumed these products daily, while we determined that daily use of rice and pasta was reported by $6.3 \%$ of females but by twice more males (Česnavičienè et al., 2015).

Studies show that products such as butter high in saturated fats are not associated with mortality rate due to cardiovascular diseases, while trans-fats (margarine) are linked to these diseases (De Souza et al., 2015). On the contrary, other authors state that butter is a contributing factor to cardiovascular mortality (Lovegrove \& Hobbs, 2016). Authors point out that consumption of butter and spreadable vegetable oil blends among Lithuanian people has changed over the time, however, a study performed in 2012 shows that about $60 \%$ of both genders used butter and spreadable vegetable oil blends (Grabauskas et al., 2013). The analysis of our study revealed that these products were used less often than once per month or were not used at all by the majority of respondents. However, only more than $2 \%$ of females reported using butter less often (less than once per month or never used) compared to females who consumed butter daily.

According to the study performed in Lithuania, confectioneries were used by $25 \%$ of students $3-5$ times per week, while one fifth of respondents did not use these products at all (Česnavičienè et al., 2015). The analysis of our study determined that considering gender, daily use of confectionery was 
reported by only $3.1 \%$ of females while the male response was negative; never or less often than once per month the use of these products was reported by $6.3 \%$ of females and by slightly more than twice males.

Literature points out that potato chips as unhealthy products are used by students. It is stated that $60 \%$ of students consume potato chips (Senikiené et al., 2016). According to our results, $32.3 \%$ of females and $24.6 \%$ of males reported never having chips or consuming them less often than once per month, and daily use was pointed out by $1.8 \%$ of males.

In the literature students' physical activity is defined by levels: high, moderate and low (Juškelienè et al., 2017). High level of physical activity is demonstrated by more than a half of Lithuanian students while the major parts of Latvian students ( $78 \%$ of males and $85 \%$ of females) are attributed to this category (Juškeliene et al., 2017; Kaupužs, 2013). Interestingly, the number of Polish students in the group of high physical activity does not exceed 50\% (Dabrowska-Galas, Plinta, Dabrowska, \& Skrzypulec-Plinta, 2013). According to our results, physical activity of the respondents does not reach 3000 MET per week; however, it exceeds 600 MET per week that suggests the moderate level of physical activity. However, a comparison of physical activity regarding intensity shows that the moderate intensity of our participants corresponds to the $\mathrm{WHO}$ recommendations, and the high intensity physical activity is even higher than recommended.

In our study, we determined that the participants of both genders spent sitting about 26 hours per week, i.e., 4 hours daily.

Literature indicates that females spend sitting more than three hours in front of the TV (Musaiger et al., 2019). It is determined that the time spent in front of the TV has a negative effect on the occurrence of anxiety, depression and poor sleep quality (Wu, Tao, Zhang, Zhang, \& Tao, 2015). Anxiety is found more frequently in females, while the presence of depression is characteristic of males - both these psychological problems affect sleep quality (Mikaliūkštienè, Gendvilaite, \& Kalibatiene, 2016). Studies show that walking has a positive effect on both physical and mental health (Bang et al., 2017). According to our studies, females walked almost twofold more than males; on average, females walked about 800 minutes per week (i.e., about 13 hours per week or 2 hours daily). However, both genders spend sitting even more time. Females and males spend sitting about 1600 minutes per week (i.e., about 26 hours per week or 4 hours daily). Therefore, we determined that the participants spent twofold more time sitting than walking.

Literature shows frequent consumption of alcohol beverages and tobacco smoking among students (Dobrovolskij et al., 2014). Our study presents quite the opposite results. The majority of participants ( $73.4 \%$ of females and $75.9 \%$ of males) reported no tobacco smoking. The frequency of alcohol consumption is slightly different: almost half of both genders used strong alcohol beverages several times per year. However, we observed that beer was consumed 2-3 times per week by $25.9 \%$ of males, and 2-3 times per month by $34.4 \%$ of females. While comparing wine consumption, we detected that the highest number of females either used it several times per year or did not use it at all.

\section{CONCLUSIONS}

According to the results, meat was consumed by two times more males than females. Ice cream was used by more males, while the use of yogurt was more frequently reported by females. Males more frequently consumed fried potatoes compared to females. Gender differences considering sitting, high intensity activity and moderate intensity activity (min per week) did not differ, however, females walked approximately two times more than males. Beer consumption was reported more frequently by males, while wine was used more frequently by females.

\section{REFERENCES}

Akhtar, N., Zareen, H., \& Sarmad, R. (2018). Eating habits and nutritional status of female students of a medical college of Lahore. Annals of King Edward Medical University, 24(1). https://doi.org/10.21649/ akemu.v24i1.2321
Bang, K. S., Lee, I., Kim, S., Lim, C. S., Joh, H. K., Park, B. J., \& Song, M. K. (2017). The effects of a campus forest-walking program on undergraduate and graduate students' physical and psychological 
health. International Journal of Environmental Research and Public Health, 14(7), 728. https://doi.org/10.3390/ ijerph14070728

Clayton, P. (2019). Tegul jūsų maistas būna jūsu vaistas. Naujas kelias i sveikata, gijima ir laime. Oksfordas.

Česnavičienè J., Proškuvienè, R., \& Motiejūnaitė, R. (2015). Lietuvos edukologijos universiteto studentų fizinio aktyvumo ir mitybos ịpročių sąsajos. Sporto mokslas, 3(81), 37-45. http://dx.doi.org/10.15823/ sm.2015.17

Dabrowska-Galas, M., Plinta, R., Dabrowska, J., \& Skrzypulec-Plinta, V. (2013). Physical activity in students of the Medical University of Silesia in Poland. Physical Therapy, 93(3), 384-392. doi: 10.2522/ptj.20120065.

Davoren, M. P., Shiely, F., Byrne, M., \& Perry, I. J. (2015). Hazardous alcohol consumption among university students in Ireland: A cross-sectional study. BMJ Open, 5(1), e006045. doi: 10.1136/bmjopen-2014-006045

Deliens, T., Clarys, P., De Bourdeaudhuij, I., \& Deforche, B. (2014). Determinants of eating behaviour in university students: A qualitative study using focus group discussions. BMC Public Health, 14(1), 53. doi: 10.1186/1471-2458-14-53

Deliens, T., Deforche, B., De Bourdeaudhuij, I., \& Clarys, P. (2015). Determinants of physical activity and sedentary behaviour in university students: A qualitative study using focus group discussions. BMC Public Health, 15(1), 201. https://doi.org/10.1186/s12889-015-1553-4

De Souza, R. J., Mente, A., Maroleanu, A., Cozma, A. I., Ha, V., Kishibe, T., ... \& Anand, S. S. (2015). Intake of saturated and trans-unsaturated fatty acids and risk of all-cause mortality, cardiovascular disease, and type 2 diabetes: Systematic review and meta-analysis of observational studies. BMJ, 351, h3978. https://doi. org/10.1136/bmj.h3978

Dobrovolskij, V., \& Stukas, R. (2014). Lietuvos aukštųjų mokyklų studentų psichoaktyviųjų medžiagų vartojimo ypatumai. Sveikatos mokslai, 24(3 (94)), 16-22.

Dobrovolskij, V., \& Stukas, R. (2015). Lietuvos aukštųjų universitetinių mokyklų studentų fizinio aktyvumo ypatumai. Visuomenés sveikata, 1, 22-30.

Grabauskas, V., Klumbienè, J., Petkevičienè, J., Šakytė, E., Kriaučionienè, V., \& Veryga, A. (2015). Suaugusių Lietuvos žmoniu gyvensenos tyrimas, 2014. Kaunas: Lietuvos sveikatos mokslų universitetas.

Grabauskas, V., Klumbienė, J., Petkevičienè, J., Šakytè, E., Kriaučionienè, V., \& Veryga, A. (2013). Suaugusių Lietuvos žmonių gyvensenos tyrimas, 2012. Kaunas: Lietuvos sveikatos mokslų universitetas.

Halimic, A., Gage, H., Raats, M., \& Williams, P. (2018). Effect of price and information on the food choices of women university students in Saudi Arabia: An experimental study. Appetite, 123, 175-182. doi: 10.1016/j.appet.2017.12.010

International Physical Activity Questionnaire Research Committee. (2005). Guidelines for data processing and analysis of the International Physical Activity Questionnaire (IPAQ). Retrieved November, 15, 2010.

Javtokas, Z., Karlienė, V., Kriaučiūnaite, A., Andriūnaitè, M., Zabelienè, I., \& Poliakovienė, R. (2014). Visuomenés sveikatos stiprinimo vadovas savivaldybems. Vilnius: Sveikatos mokymo ir ligų prevencijos centras.

Juškelienė, V., \& Česnavičienė, J. (2017). Physical activity and its determinants among first-year students of Lithuanian University of Educational Sciences. Pedagogika, 128(4). http://dx.doi.org/10.15823/p.2017.65

Karmakar, P., Jahan, N., Banik, S., Das, A., \& Rahman, K. A. (2016). Food habits, obesity and nutritional knowledge among the university students in Noakhali region of Bangladesh: A Cross Sectional Study. Journal of Food and Nutritional Disorders, 5, 4. doi: http://dx. doi. org/10.4172/2324, 9323, 2.

Kaupužs, A. (2013). The relationship between physical activity and exercise motivation of the first year students from Rezekne Augstskola. LASE Journal of Sport Science, 4(1), 3-15.

Ministry of Health of the Republic of Lithuania. (2018). Sveikos mitybos rekomendacijos. Retrieved from https:// sam.lrv.lt/lt/veiklos-sritys/visuomenes-sveikatos-prieziura/mityba-ir-fizinis-aktyvumas-2/sveikos-mitybos-rekomendacijos

Lovegrove, J. A., \& Hobbs, D. A. (2016). New perspectives on dairy and cardiovascular health. Proceedings of the Nutrition Society, 75(3), 247-258.

Mikaliūkštienè, A., Gendvilaite, V., \& Kalibatienè, D. (2016). Studentų psichoemocinès būklès ir miego kokybès sąsajos. Medicinos teorija ir praktika, 22(4), 291-300.

Moreno-Gómez, C., Romaguera-Bosch, D., TaulerRiera, P., Bennasar-Veny, M., Pericas-Beltran, J., Martinez-Andreu, S., \& Aguilo-Pons, A. (2012). Clustering of lifestyle factors in Spanish university students: the relationship between smoking, alcohol consumption, physical activity and diet quality. Public Health Nutrition, 15(11), 2131-2139.

Musaiger, A. O., Al-Khalifa, F., \& Al-Mannai, M. (2016). Obesity, unhealthy dietary habits and sedentary behaviors among university students in Sudan: Growing risks for chronic diseases in a poor country. Environmental Health and Preventive Medicine, 21(4), 224-230. doi: 10.1007/s12199-016-0515-5

Oyebode, O., Gordon-Dseagu, V., Walker, A., \& Mindell, J. S. (2014). Fruit and vegetable consumption and all-cause, cancer and CVD mortality: Analysis of Health Survey for England data. Journal of Epidemiology and Community Health, 68(9), 856-862. https://doi. org/10.1136/jech-2013-203500

Petkevičienė, J., Kriaučionienė, V., \& Petrauskienè, A. (2014). Visuomenés sveikata ir mityba. Metodinis leidinys / mokomoji knyga. Kaunas: Lietuvos sveikatos mokslų universitetas. 
Samsonienė L, \& Zimnicka V. (2013). Studentų mitybos ipročiai. Sveikatos mokslai, 23(1), 109-112. doi: 10.5200/sm-hs. 2013.020

Senikienè, Ž., Lukoševičius, A., Jurkštienè, V., Šimonienè-Kazlauskienè, G., \& Gintilienè, M. (2016). Studentų mitybos ippročių analizè. Sveikatos mokslai, 26(6), 65-71. doi: 10.5200/sm-hs.2016.093

Sigmundova, D., Chmelik, F., Sigmund, E., Feltlova, D., \& Frömel, K. (2013). Physical activity in the lifestyle of Czech university students: Meeting health recommendations. European Journal of Sport Science, 13(6), 744-750.

Strukčinskienè, B., Pačiauskaitè, I., Griškonis, S., Strukčinskaitè, V., Stasiuvienė, D., \& Griškonytė, I. (2014). Klaipėdos miesto gyventojų gyvensena: fizinio aktyvumo ypatumai. Visuomenès sveikata, 24(5), 16-19. doi: 10.5200/sm-hs.2014.086

WHO. (2010). Diet and physical activity factsheet. Recommendations. Retrieved from http://www.who.int/ dietphysicalactivity/factsheet_recommendations/en/).

WHO. (2013). Global Action Plan for the Prevention and Control of NCDs 2013-2020. Retrieved from https:// www.who.int/nmh/events/ncd_action_plan/en/

World Health Organization. (2015). Guideline: Sugars intake for adults and children. Switzerland: WHO.

Wu, X., Tao, S., Zhang, Y., Zhang, S., \& Tao, F. (2015). Low physical activity and high screen time can increase the risks of mental health problems and poor sleep quality among Chinese college students. PloS One, 10(3), e0119607. doi: 10.1371/journal.pone.0119607 